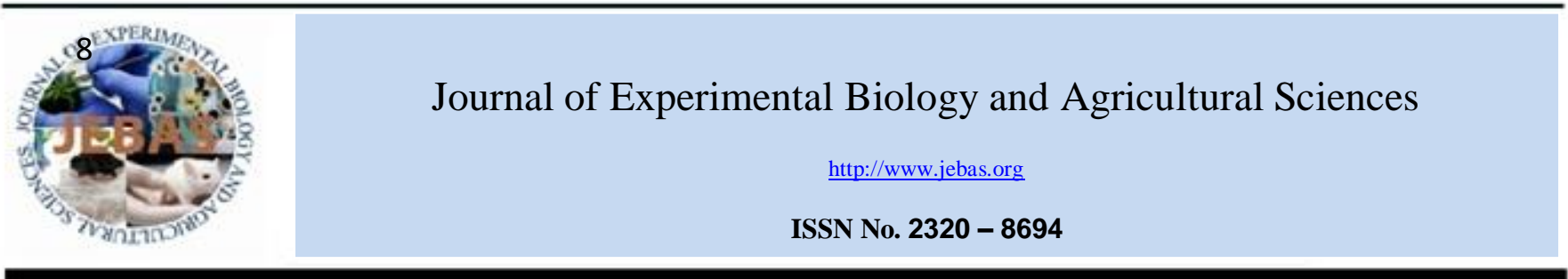

\title{
ASSESSMENT OF CULTURABLE MICROBIAL DIVERSITY OF DHOLERA THERMAL SPRINGS OF GUJARAT, INDIA
}

\author{
Disha N. Patel ${ }^{1,2^{*}}$, Shailesh R. Dave ${ }^{2}$, Vincent J. Braganza ${ }^{2}$, Hasmukh A. Modi ${ }^{1}$ \\ ${ }^{1}$ Department of Lifesciences, Gujarat University, Ahmedabad, India. \\ ${ }^{2}$ Xavier Research Foundation, Loyola Centre for Research \& Development, Ahmedabad, India.
}

Received - November 22, 2018; Revision - December 27, 2018; Accepted - January 11, 2019

Available Online - February 5, 2019

DOI: http://dx.doi.org/10.18006/2019.7(1).57.64

\section{KEYWORDS}

Hot spring

Thermophilic bacteria

Physicochemical analysis

Biochemical analysis

Ecological indices

$16 \mathrm{~S}$ rRNA gene sequencing

\section{ABSTRACT}

The present study deals with bacterial diversity study based on cultivation of the organisms from the Dholera hot springs of Gujarat, India during various seasons. Isolation was carried out by spread plate and streak plate method. Isolates were characterized based on colony and morphological characteristics. Various biochemical tests and 16S rRNA gene analysis were performed for identification of thermophilic bacteria. A total of 18 isolates were cultivated using different types of media. Out of the total 18 isolates, eight were Gram-positive and ten were Gram-negative. Based on the biochemical test of these isolates, 8 were found to produce catalase, 18, 18 and 8 isolates utilized casein, starch, and citrate respectively. Further, 9 isolates were produced $\mathrm{H}_{2} \mathrm{~S}$ by sulphate reduction. Sugar utilization varied in all the isolates. Diversity of the isolates were studied in terms of Simpson, Shanon, Menhinick, Margalef, Berger-Parker and Chao-1 based on the metabolic activity of thermophilic bacteria. Six wellisolated purified colonies were selected for 16S rRNA gene sequence analysis. Based on the molecular identification, these isolated bacterial isolates belonged to genera Bacillus, Brevibacillus, Brevibacterium and Tepidomonas. All these thermophilic isolates may have valuable application at an industrial level and for biotechnological purposes.
* Corresponding author

E-mail: dishu.patel85@gmail.com (Disha N. Patel)

Peer review under responsibility of Journal of Experimental Biology and Agricultural Sciences.

Production and Hosting by Horizon Publisher India [HPI] (http://www.horizonpublisherindia.in/).

All rights reserved.
All the article published by Journal of Experimental Biology and Agricultural Sciences is licensed under a Creative Commons Attribution-NonCommercial 4.0 International License Based on a work at www.jebas.org.

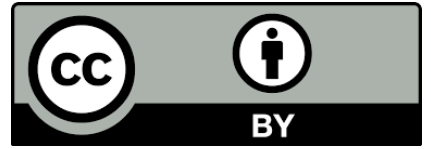




\section{Introduction}

Hot springs diversity have been studied worldwide, which are reported as a normal source of several thermophilic bacteria. Geothermal springs are significant spots of microbial biodiversity, having the capacity to produce various enzymes for industrial, agriculture and medical research processes and are also helpful to get novel genes as well as molecules (Saxena et al., 2016; Sahay et al., 2017). Thermophiles are heat-loving microbes, therefore they can grow at $45^{\circ} \mathrm{C}$ to $75^{\circ}$ $\mathrm{C}$ with optimum temperature range between $50^{\circ} \mathrm{C}$ and $60^{\circ} \mathrm{C}$. Some of the thermophilic microorganisms tolerate a higher temperature for their survival and growth, whereas other thermophiles tolerate a comparatively lower temperature (Hartmann et al., 1989; Pelczar et al., 1993; Panikov et al., 2003; Eze et al., 2011). The special attraction of hot water springs is the ecological variation of different types of microorganisms and their molecular characteristics (Adiguzel et al., 2011; Genc et al., 2015). Thermophilic bacteria represent both Gram-positive and Gram-negative group and they also belongs to aerobic and anaerobic groups of bacteria. Due to their various valuable applications, researchers have focused their research to find out new genus and species of microorganisms around the world (Yoneda et al., 2013; Cihan et al., 2014; Aanniz et al., 2015).

There are several hot springs available in Gujarat. Some studies have been carried out on thermophilic bacteria in TuvaTimba, Lasundra, Tulsishyam, Dholera and Unai (Kikani \& Singh 2011; Chudasama 2012; Joshi et al., 2013; Gohel et al., 2013; Dudhagara et al., 2014). Present study was conducted at Dholera hot water spring and focus on seasonal variations of thermophilic organism's isolates from this ecosystem. Information regarding the microbial community of Dholera hot spring is available in scarcity. The aim of present study was to characterize the thermophilic bacteria from Dholera hot spring in three different seasons and the interest was to find out novel species at this site.

\section{Materials and Methods}

\subsection{Sample collection}

Hot spring water samples were collected from Dholera hot spring $\left(22^{\circ} 15^{\prime} 0 " \mathrm{~N} \quad 72^{\circ} 11^{\prime} 27^{\prime \prime} \mathrm{E}\right)$, Gujarat. Dholera is an ancient port-city in Gulf of Khambhat, $30 \mathrm{~km}$ from Dhandhuka city of Ahmedabad district, Gujarat. Water samples were collected in sterile glass bottles from Dholera hot water spring in three different seasons: monsoon (September), winter (January) and summer (April). Samples were transported in a thermocol box to the laboratory and processed on the same day of the sampling and then stored at room temperature.

\subsection{Physicochemical analysis}

Temperature and $\mathrm{pH}$ of collected samples were recorded at the time of sampling using portable $\mathrm{pH}$ meter. Conductivity, TDS and salt of the collected samples were measured in the laboratory using Oakton Thermo, Multi-parameter PCS Testr 35, and Thermo Fisher Scientific.

\subsection{Isolation of bacteria}

Samples were processed for isolation of bacteria on the same day of the sample collection. Thermophilic microorganisms were isolated directly from water samples by serial dilution technique using various media like Nutrient agar medium (0.5\% Peptone, $0.3 \%$ Beef extract, $0.5 \% \mathrm{NaCl}, 2.0 \%$ Agar), Luria-Bertani medium (1.0\% Tryptone, $1.0 \% \mathrm{NaCl}, 0.5 \%$ yeast extract, $2.0 \%$ Agar), ATCC Thermus medium $(0.5 \% \mathrm{NaCl}, 0.5 \%$ Peptone, $0.4 \%$ Beef extract, $0.2 \%$ Yeast extract, $2.0 \%$ Agar), Starkey`s sulphate reducing medium (Himedia M1981), Sulphate reducing medium (Himedia M803) and Medium77 medium $\left(0.5 \% \mathrm{~K}_{2} \mathrm{HPO}_{4}, 1.0 \%\right.$ $\mathrm{NH}_{4} \mathrm{Cl}, 0.1 \% \mathrm{CaCl}_{2} .2 \mathrm{H}_{2} \mathrm{O}, 0.1 \% \quad \mathrm{MgSO}_{4} .7 \mathrm{H}_{2} \mathrm{O}, 5.0 \%$ Sodium lactate, $1.0 \%$ Yeast extract, $5.0 \% \quad \mathrm{FeSO}_{4} .7 \mathrm{H}_{2} \mathrm{O}, 1.0 \%$ Sodium thioglycolate, $1.0 \%$ Ascorbic acid, 2.0\% Agar ( Patil et al., 2014). All the plates were incubated at $45 \pm 2{ }^{\circ} \mathrm{C}$ and $50 \pm 2{ }^{\circ} \mathrm{C}$. After the growth, morphologically distinct colonies were selected and subcultured on respective medium to get pure isolates. Then from these well isolated purified colonies, $20 \%$ glycerol stocks of bacterial cultures were prepared for preservation and further study on the isolates.

\subsection{The conventional method for identification and characterization of the isolates}

The selected isolates were observed for morphological and growth characteristics by the conventional methods as outline below. The bacterial isolates were characterized by Gram staining and observed under light microscope. The thermophilic isolates were identified by conventional, physiological methods and characterised based on biochemical identification tests. These tests are characterized based on Gram nature, shape, temperature, $\mathrm{pH}$, catalase production test, casein utilization test, starch utilization test, citrate utilization test, Sugars profile like DGlucose, D-Fructose, Maltose, Mannose, Sucrose, Mannitol, Lactose, Xylose, Galactose, $\mathrm{H}_{2} \mathrm{~S}$ production test and Sulphate reduction test as per the Bergy's manual (Hensyl, 1994).

\subsection{Diversity indices}

A range of diversity indices profile, cluster analysis and similarity in diversity were generated using statistical software Paleontological Statistics (PAST) considering the results of biochemical tests (Hammer et al., 2001). 


\subsection{Genomic DNA isolation}

Bacterial broth cultures $(2-5 \mathrm{ml})$ were grown in log phase at $45 \pm$ $2{ }^{\circ} \mathrm{C}$ and $50 \pm 2{ }^{\circ} \mathrm{C}$ for 24 hours. Overnight cultures $(2.0 \mathrm{ml})$ were centrifuged at $10,000-15,000 \mathrm{X} \mathrm{g}$ for 15 minutes. The supernatant was decanted and pellet was collected and resuspended in $1 \mathrm{ml}$ of TE buffer. The DNA was quantified by NanoDrop spectrophotometer by taking absorbance at 260 and $280 \mathrm{~nm}$ (Nucleic acid software). The size of DNA was estimated by agarose gel $(0.5 \% \mathrm{~W} / \mathrm{V})$ electrophoresis subsequent staining with ethidium bromide and visualisation in U.V. illumination by Gel Documentation System (Gene snap software). Genomic DNA was isolated from the obtained pallets from pure cultures using the miniprep method described by Wilson with some modifications (Moore et al., 2004; Wilson, 1987). The obtained DNA pellets stored at $4{ }^{\circ} \mathrm{C}$ for further analysis. $16 \mathrm{~S}$ rRNA gene sequence analysis was done at Chromous Biotech (Bangalore).

\section{Results}

\subsection{Physicochemical characteristics}

Physicochemical characteristics of water samples of Dholera hot spring are listed in Table 1. Dholera water spring was covered with cement concrete construction, hence the soil sample was not available. The temperature of the water was $40^{\circ} \mathrm{C}$ to $50^{\circ} \mathrm{C}$ in Dholera. The TDS (Total Dissolved Salt) value varied from 3.1 to 3.7 ppt (parts per thousand) in Dholera. Observed $\mathrm{pH}$ value was 7.1 to 7.9 at Dholera sampling point. Conductivity of the studied water samples were reported between 4.4 to $4.9 \mathrm{mS}$ (milliSiemens). Whereas seasonal physicochemical variations were concerned, the temperature in summer was at high of $50{ }^{\circ} \mathrm{C}$ and at low of $40^{\circ} \mathrm{C}$ in winter, which is significant. Overall seasonal differences in conductivity, TDS and salt concentration in Dholera samples were in the range of $10 \%$.

\subsection{Microbial analysis}

Total 18 morphologically different isolates were isolated and purified from the water samples collected from Dholera hot springs during summer, monsoon and winter season using Nutrient agar medium, Luria-Bertani medium, ATCC Thermus medium, Starky`s medium, Sulphate reducing medium and Medium77 medium. Out of these isolates; eight isolates were Gram-positive while rest ten were Gram-negative. A wide range of pigmented colonies was observed as shown in table 2. The colours of the pigmented colonies observed were distributed over cream, brown, light brown, black and yellow.

\subsection{Metabolic activity based on the biochemical test}

Various metabolic activities were assessed to have a broad view of the characterization of bacteria, on the behalf of these isolated strains were identified. Out of 18 isolated isolates, catalase

Table 1 Morphological observation of all isolates of Dholera hot springs

\begin{tabular}{|lcl|}
\hline Isolates & Colony observation & Gram nature \\
\hline DW49 & Cream & Gram-positive \\
\hline DW50 & Cream & Gram-positive \\
\hline DW51 & Brown & Gram positive \\
\hline DW52 & Brown & Gram-negative \\
\hline DW53 & Brown & Gram-negative \\
\hline DW54 & Blackish & Gram-negative \\
\hline DW55 & Cream & Gram-positive \\
\hline DW56 & Light brown & Gram-positive \\
\hline DW57 & Yellow & Gram-positive \\
\hline DW58 & Brown & Gram-negative \\
\hline DW59 & Brown & Gram-negative \\
\hline DW60 & Blackish & Gram-negative \\
\hline DW61 & Cream & Gram-negative \\
\hline DW62 & Cream & Gram-positive \\
\hline DW63 & Light brown & Gram-positive \\
\hline DW64 & Brown & Gram-negative \\
\hline DW65 & Brown & Gram-negative \\
\hline DW66 & & Gram-negative \\
\hline
\end{tabular}

Table 2 Season-wise physicochemical characteristics observed in samples from Dholera

\begin{tabular}{|cccc|}
\hline Dholera & Summer & Monsoon & Winter \\
\hline Temperature & $50{ }^{\circ} \mathrm{C}$ & $45^{\circ} \mathrm{C}$ & $4{ }^{\circ} \mathrm{C}$ \\
\hline $\mathrm{pH}$ & 7.9 & 7.2 & 7.1 \\
\hline Conductivity & $4.9 \mathrm{~ms}$ & $4.5 \mathrm{~ms} \mathrm{~ms}$ \\
\hline TDS & $3.7 \mathrm{ppt}$ & $3.4 \mathrm{ppt}$ & $3.1 \mathrm{ppt}$ \\
\hline Salt & $2.42 \mathrm{ppt}$ & $2.38 \mathrm{ppt}$ & $2.38 \mathrm{ppt}$ \\
\hline
\end{tabular}

Journal of Experimental Biology and Agricultural Sciences http://www.jebas.org 
production was showed by 8 isolates. Further, 18, 18 and 9 isolates were able to utilize casein, starch and citrate respectively. $\mathrm{H}_{2} \mathrm{~S}$ production and sulphate reduction properties were reported in nine isolates while sugars metabolism activity varied in all the isolates.

The results of the water samples are summarized in Figure 1. Catalase production was dominant in summer and monsoon seasons isolates, while it was indicated significantly lower in winter season`s isolates. On the other hand, all the three seasons isolates showed positive results for the casein and starch utilization. Citrate utilization was dominant in all three seasons. Sugars profile like fructose, maltose and glucose were positively utilized in all Dholera summer season`s isolates. Rest of the monsoon season`s isolates indicated positive results for utilization of fructose and glucose. Galactose and glucose were also positive in all isolates of winter season`s samples. In the summer and winter season`s isolates, xylose showed positive results in only one isolate. $\mathrm{H}_{2} \mathrm{~S}$ production and Sulphate reduction were dominant in all three seasons.

3.4 Cluster analysis and diversity indices based on metabolic activity

Diversity study of various isolates was carried out in terms of 15 biochemical tests on the basis of their results dendrograms were prepared, and are shown in Figure 2. The blue colour label indicates summer season, green colour indicates the monsoon season and pink colour indicates winter season. All the isolates obtained from water samples collected from Dholera were divided into 2 major group as A and B (Figure 2). B group showed sulphate reducing isolates in all three seasons based on their biochemical results.

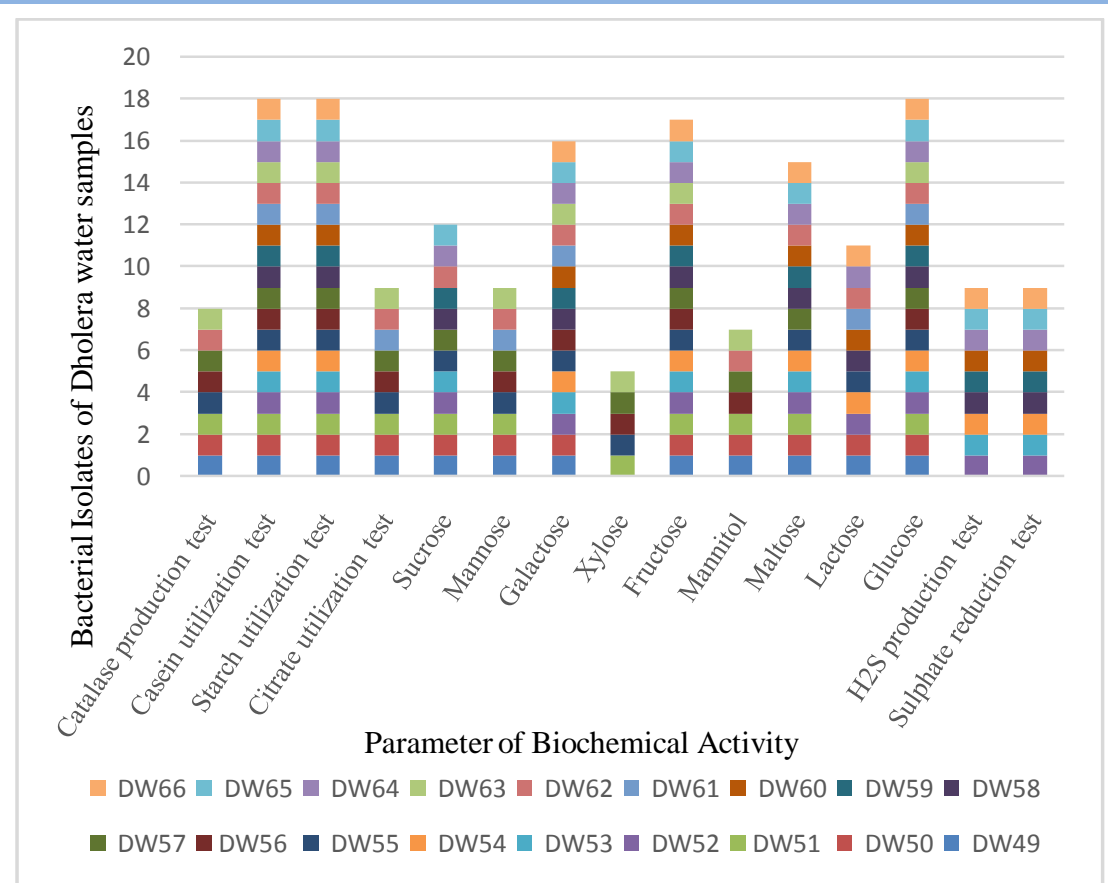

Figure 1 Comparison of metabolic activities of the isolated bacteria from Dholera hot spring water samples [collected during summer (DW49-DW54), winter (DW55-DW60) and monsoon (DW61-DW66) season] DW49 to DW66 are the bacterial isolates.

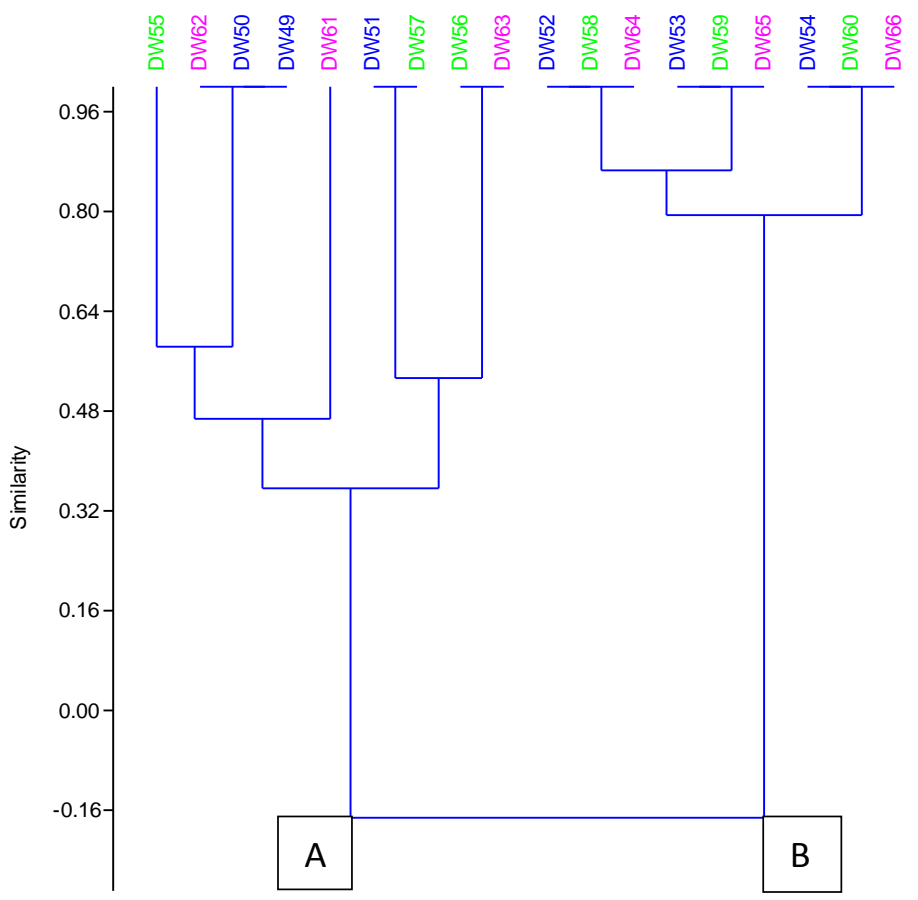

Figure 2 Dholera water seasonal cluster analysis

Cluster analysis of all seasonal samples. [Seasons are colour indicated [Summer (DW49-DW54) Monsoon (DW55-DW60), Winter (DW61-DW66)(Summer-Blue colour, Monsoon- Green colour, Winter - Pink colour)] 
Morphologically distinct isolates from Dholera thermal ecosystem were studied to determine their similarity. From Dholera samples total 18 colonies were selected from water samples. Irrespective of the seasonal collection distinct isolates range from 6 to 9 in each sample (Data not shown). Among the different isolates studied the maximum similarity between any 2 isolates was 86 87 per cent. Except for DW - 49 and DW - 50 which showed 100 per cent similarity and they were identified as Bacillus subtillis based on 16S rRNA partial gene sequence analysis.

Diversity indices data in terms of Taxa_S, Individuals, Dominance, Simpson, Shanon, Menhinick, Margalef, BergerParker and Chao-1 were also studied for all the samples collected in the different seasons from the Dholera hot spring ecosystem (Table 3 ).

\subsection{Molecular identification of selected organisms}

From the total 18 isolates 6 colonies were selected randomly and these isolates were identified based on 16S rRNA gene sequence analysis and results are shown in Table 4. Among the 6 identified cultures three belong to Bacillus genus, one to Brevibacillus, one to Brevibacterium and one to Tepidimonas. The details of NCBI identification numbers are given in Table 4.

\section{Discussion and Conclusion}

In some hot springs, the physicochemical parameters have been observed to vary with the seasonal effect. While in other studies it has been reported that, the physicochemical parameters can be stable with no significant changes in seasonal effect. Moreover seasonal variation in microbial diversity is low in hot springs due to the high temperature of the springs (Ferris \& Ward, 1997; Mackenzie et al., 2013; Briggs et al., 2014; Prieto-Barajas et al., 2017). The prevalent conditions in hot springs such as high water temperature, $\mathrm{pH}$, sulphur concentration, salinity, conductivity and other physicochemical parameters are known to permit the development of selected bacterial communities (Nayak, 2013). In the current study, biochemical tests determined the metabolic activity of the bacterial cells (Goh et al., 2012; Nayak, 2013). Diversity indices tools have been used for the population of bacterial diversity, species richness and also better understanding about microbial community (Kim et al., 2017). Kikani et al. (2015), calculated the various diversity indices of Tulsi Shyam hot spring, Gujarat. They have given information about the evenness in their distribution, community structure and species richness (Kikani et al., 2015). 16S rRNA gene sequencing techniques have been used for the identification of bacteria and phylogenetic

Table 3 Comparison of selected diversity indices of isolates from both ecosystem during sampling season

\begin{tabular}{|cccc|}
\hline \multirow{2}{*}{ Index } & \multicolumn{3}{c|}{ Dholera Water } \\
\cline { 2 - 4 } & Summer & Monsoon & 15 \\
\hline Taxa_S & 15 & 15 & $18-23$ \\
\hline Individuals & $18-21$ & 0.07 & 0.07 \\
\hline Dominance & 0.07 & 0.92 & 0.92 \\
\hline Simpson & 0.92 & 2.6 & 2.6 \\
\hline Shannon & 2.6 & $3.2-3.5$ & $3.1-3.5$ \\
\hline Menhinick & $3.2-3.5$ & $4.5-4.8$ & $4.4-4.8$ \\
\hline Margalef & $4.5-4.8$ & $0.09-0.1$ & $0.08-0.1$ \\
\hline Berger-Parker & $0.09-0.1$ & $20.1-31.5$ & $17.3-31.5$ \\
\hline Chao-1 & $20.1-31.5$ & & \\
\hline
\end{tabular}

Table 4 Detail of NCBI identification

\begin{tabular}{|cccc|}
\hline Sequence number & Isolates name & Accession number & Isolates number \\
\hline XRF14 & Brevibacterium halotolerans & MH426315 & DW56 \\
\hline XRF21 & Tepidimonas Taiwanese & MH426322 & DW55 \\
\hline XRF23 & Brevibacillus brostelensis & MH426324 & DW50 \\
\hline XRF24 & Bacillus subtillis & MH426325 & DW57 \\
\hline XRF31 & Bacillus sonorensis & MH614333 & DW49 \\
\hline XRF32 & Bacillus subtillis & MH614334 & \\
\hline
\end{tabular}

Journal of Experimental Biology and Agricultural Sciences http://www.jebas.org 
analysis as the "gold standard" (Ludwig \& Schleifer 1999). It has been reported that molecular-based identification of thermophilic bacteria by $16 \mathrm{~S}$ rRNA gene sequencing is useful at the genus level identification (Sahin et al., 2009). It has earlier been reported that some thermophilic Bacillus species are a source for useful enzymes for industrial and commercial purposes (Rahman et al., 1994; Rao et al., 1998; Dudhagara et al., 2014). In previously published reports, Bacillus spp from the genus Bacillus have been claimed to be largest and the best studied genus (De Boer et al., 1994; Kolsto et al., 2009; Nayak, 2013). Species of genus Bacillus have been found in Lasundra, TuvaTimba, Unai hot springs of Gujarat and these bacillus species have been used for various applications like production of enzyme, biosurfactant, and thermostability etc (Kikani \& Singh, 2011; Joshi et al., 2013; Gohel et al., 2013; Dudhagara et al., 2014). According to Hadad et al. (2005) thermophilic bacterium Brevibacillus brostelensis isolated from soil, and this strain plays an important role in biodegradation of polythene (Hadad et al., 2005). $B$. brostelensis, thermophilic bacteria has been reported from Saudi Arabia hot spring and possesses enzyme having ability to degrade polythene substrates (Khalil et al., 2018). Tepidimonas taiwanensis strain was first reported in a Southern Taiwan hot water spring and it was claimed to be a novel species. Among the Tepidimonas genus, this strain was able to produce alkaline protease enzyme for industrial application (Chen et al., 2006).

The focus of this preliminary study was a comparison of the seasonal diversity of Dholera hot spring. Further present investigation also focused on the identification of seasonal diversity to get novel species. Based on bacterial identification study, almost similar numbers of isolates were found in all seasons of Dholera hot spring.16S rRNA sequence-based molecular identification shows a good amount of correlation with the biochemical identification of thermophilic bacteria. The presence of $T$. taiwanensis species is reported for the first time in the Dholera hot springs of Gujarat. Based on our morphological and biochemical studies the isolates divided in two major groups such as sulphate reducers and sulphate nonreducers.

\section{Acknowledgement}

Authors are thankful to "Xavier Research Foundation" for supporting our research and providing grant and good lab facilities.

\section{Conflict of interest}

Author declares that there is no conflict of interest.

\section{References}

Aanniz T, Ouadghiri M, Melloul M, Swings J, Elfahime E, Ibijbijen J, Ismaili M, Amar M (2015) Thermophilic bacteria in Moroccan hot springs, salt marshes and desert soils. Brazilian Journal of Microbiology 46: 443-453.

Adiguzel A, Inan K, Sahin F, Arasoglu T, Gulluce M, Belduz AO, Baris O (2011) Molecular diversity of thermophilic bacteria isolated from Pasinler hot spring (Erzurum, Turkey). Turkish Journal of Biology 35: 267-274.

Briggs BR, Brodie EL, Tom LM, Dong H, Jiang H, Huang Q, Wang S, Hou W, Wu G, Huang L, Hedlund BP, Zhang C, Dijkstra $P$, Hungate BA (2014) Seasonal patterns in microbial communities inhabiting the hot springs of Tengchong, Yunnan Province China. Environmental Microbiology 16:1579-1591.

Chen TL, Chou YJ, Chen WM, Arun B, Young CC (2006) Tepidimonas taiwanensis Sp. Nov., a Novel Alkaline-ProteaseProducing Bacterium Isolated from a Hot Spring. Extremophiles $10: 35-40$.

Chudasama CJ (2012) Isolation, Screening and Characterization of Alkaline Protease producing Microorganisms PhD submitted to the Sardar Patel University.

Cihan AC, Cokmus C, Koc M, Ozcan B (2014) Anoxybacilluscalidus sp. nov., a thermophilic bacterium isolated from soil near a thermal power plant. International Journal of Systematic and Evolutionary Microbiology 64: 211-219.

De Boer AS, Priest F, Diderichsen B (1994) On the industrial use of Bacillus licheniformis: a review. Applied Microbiology and Biotechnology 40: 595-598.

Dudhagara P, Bhavasar P, Ghelani A, Bhatt S (2014) Isolation, Characterization and Investing the industrial applications of thermostable and solvent tolerant serine protease from hot spring isolated thermophilic Bacillus licheniformis U1. International Journal of Applied Science and Biotechnology 2: 75-82.

Eze UN, Okonji RE, Ibraheem O, Shonukan OO (2011) Isolation and characterization of a bacterial thermostable protease from poultry dung. Ife Journal of Science 13: 2 .

Ferris MJ, Ward DM (1997) Seasonal distributions of dominant 16S rRNA-defined populations in a hot spring microbial mats examined by denaturing gradient gel electrophoresis. Applied and Environmental Microbiology 63: 1375-1381.

Genc B, Nadaroglu H, Adiguzel A, Baltaci O (2015) Purificationand characterization of an extracellular cellulase from 
Anoxybacillus gonensis 09 isolated from geothermal area in Turkey. Journal of Environmental Biology 36:1319-1324.

Goh YM, Love PED, Brown H, Spickett J (2012) Organizational Accidents: A Systemic Model of Production versus Protection. Journal of Management Studies 49: 52-76.

Gohel HR, Ghosh SK, Braganza VJ (2013) Production, Purification and Immobilization of extracellular lipase from Thermophilic Bacillus subtillis XRF11 and Bacillus licheniformis XRF12 for production of alkyl esters. International Journal of Life Sciences Biotechnology and Pharma Research 2 : 278-286.

Hadad D, Geresh S, and Sivan A (2005) Biodegradation of Polyethylene by the Thermophilic Bacterium Brevibacillus Borstelensis. Journal of Applied Microbiology 98(5): 1093-1100.

Hammer R, Harper D, Ryan P (2001) PAST : Paleontological Statistics Software Packages for Education and Data Analysis. Palaeontologia Electronica 4:9.

Hartmann RF, Wolter SJ, Kroger B, Schultze S, Specht T, Erdmann VA (1989) Does thermos represent another deepeubacteria branching. Systematic and Applied Microbiology 11: 243-251.

Hensyl WR (1994). Bergey's Manual of Systematic Bacteriology. 9th Edition., Williams and Wilkins, Baltimore.

Joshi SJ, Suthar H, Yadav AK, Hingurao K, Nerurkar A (2013) Occurrence of Biosurfactant Producing Bacillus Spp . in Diverse Habitats. ISRN Biotechnology. Volume 2013, Article ID 652340, 6 pages.

Khalil AB, Sivakumar N, Arslan M, Saleem H, Qarawi S (2018) Insights into Brevibacillus Borstelensis AK1 through Whole Genome Sequencing: A Thermophilic Bacterium Isolated from a Hot Spring in Saudi Arabia. BioMed Research International. April 2018. Article ID 5862437.

Kikani BA, Singh SP (2011) Single step purification and characterization of a thermostable and calcium independent amylase from Bacillus amyloliquifaciens TSWK1-1 isolated from Tulsi Shyam hot spring reservoir, Gujarat (India). International Journal of Biological Macromolecules 48:676-681.

Kikani BA, Sharma AK, Singh SP (2015) Culture Dependent Diversity and Phylogeny of Thermophilic Bacilli from a Natural Hot Spring Reservoir in the Gir Forest, Gujarat (India). Microbiology $84: 687-700$.

Kim BR, Shin J, Guevarra RB, Lee JH, Kim DW, Seol KH, Lee JH, Kim HB, Isaacson RE (2017) Deciphering Diversity Indices for a Better Understanding of Microbial Communities. Journal of Microbiology and Biotechnology 27 : 2089-2093.
Kolsto AB, Tourasse NJ, Okstad OA (2009) What sets Bacillus anthracis apart from other Bacillus species? Annual Review of Microbiology 63: 451-476.

Ludwig W, Schleifer KH (1999) Phylogeny of bacteria beyond the 16S rRNA standard. ASM News 65: 752-757.

Mackenzie R, Pedrós-Alió C, Díez B (2013) Bacterial composition of microbial mats in hot springs in Northern Patagonia: variations with seasons and temperature. Extremophiles 17, 123-136.

Moore E, Arnscheidt A, Krüger CAMB, Strompl C, Mau M (2004) Simplified protocols for the preparation of genomic DNA from bacterial cultures. Molecular Microbial Ecology Manual 1.01: 3-18.

Nayak SP (2013) Identification and Characterization of Thermophilic bacteria from hot springs of Odisha and their potential applications. Thesis Submitted to the Department of Microbiology, Orissa university of Agriculture and Technology. Bhubaneswar-3. Odisha. India.

Panikov NS, Popova NA, Dorofeev AG, Nicolaeve YA, Verkhovtseva NV (2003) Growth of the thermophilicbacteria Geobacillus urdicus as a function oftemperature and $\mathrm{pH}$ : An SCM-Basedkinetic analysis. Microbioogy 7 : 277-284.

Patil SZ, Unnithan AR, Unnikrishan (2014) Biosulphidogenesi: Isolation and Characterization of Thermodesulfo bacterium Commune Sp. Nov. Isolated from Hot Water Springs of Thane, Maharashtra. IOSR Journal of Pharmacy and Biological Sciences $9: 09-13$.

Pelczar J, Chan ECS, Krieg NR (1993) Microbiology Concepts and Applications. Philadelphia, Hong Kong, London, Munich. Pp263 - 264.

Prieto-Barajas CM, Alfaro-Cuevas R, Valencia-Cantero E, Santoyo G (2017) Effect of seasonality and physicochemical parameters on bacterial communities in two hot spring microbial mats from Araró, Mexico. Revista Mexicana de Biodiversidad 88:616-624.

Rahman RNZA, Razak CN, Ampon K, Basri M, Zin WM, Yunus W, Salleh AB (1994) Purification and characterization of a heat-stable alkaline protease from Bacillus stearothermophilus F1. Applied Microbiology and Biotechnology 40:822-827.

Rao MB, Tanksale AM, Ghatge MS, Deshpande VV (1998) Molecular and biotechnological aspects of microbial proteases. Microbiology and Molecular Biology Reviews $62: 597-635$. 
Sahay H, Yadav AN, Singh AK, Singh S, Kaushik R, Saxena AK (2017) Hot springs of Indian Himalayas: potential source of microbial diversity and thermostable hydrolytic enzymes. Biotechnology, 7:118.

Sahin TN, Pinker S, Cash SS, Schomer D, Halgre E (2009) Sequential Processing of Lexical, Grammatical, and Phonological Information Within Broca's Area. Science 326 : 445-449.

Saxena AK, Yadav AN, Rajawat M, Kaushik R, Kumar R, Kumar M,Prasanna R, Shukla L (2016) Microbial diversity of extremeregions: an unseen heritage and wealth. Indian Journal of
Plant Genetic Resources 29:246-248.

Wilson K (1987) Preparation of Genomic DNA from Bacteria. In: Ausubel FM, Brent R, Kingston RE, Moore DD, Seidman JG, Smith JA, Struhl K (Eds.), Current Protocols in Molecular Biology, Wiley \& Sons, New York, Pp. 241-245.

Yoneda Y, Yoshida T, Yasuda H, Imada C, Sako Y (2013) Athermophilic, hydrogenogenic and carboxydotrophic bacterium, Calderihabitans maritimus gen. nov., sp. nov., from a marinesediment core of an undersea caldera. International Journal of Systematic and Evolutionary Microbiology 63: 3602-3608.

Journal of Experimental Biology and Agricultural Sciences http://www.jebas.org 